\title{
Kernos
}

Revue internationale et pluridisciplinaire de religion grecque antique

22 | 2009

Varia

\section{Serious Singing: The Orphic Hymns as Religious Texts}

Fritz Graf

\section{(apenEdition \\ Journals}

\section{Electronic version}

URL: http://journals.openedition.org/kernos/1784

DOI: 10.4000/kernos. 1784

ISSN: 2034-7871

\section{Publisher}

Centre international d'étude de la religion grecque antique

\section{Printed version}

Date of publication: 1 January 2009

Number of pages: 169-182

ISSN: 0776-3824

Electronic reference

Fritz Graf, «Serious Singing: The Orphic Hymns as Religious Texts », Kernos [Online], 22 | 2009, Online since 26 October 2012, connection on 19 April 2019. URL : http://journals.openedition.org/ kernos/1784; DOI : 10.4000/kernos.1784 
Kernos 22 (2009), p. 169-182.

\title{
Serious Singing: The Orphic Hymns as Religious Texts
}

\begin{abstract}
In the wake of Albrecht Dieterich, in this paper I try to show how the overall arrangement of the hymns in the Orphic hymn book follows the progression of a nocturnal ritual. I insist on the frequency with which the hymns talk about the fear of meeting a divinity or a phasma that would be in an unkind and violent state and could drive the initiates into madness. Thus, the hymns construct the mystery experience as an event that is, at least in part, dangerous and frightening. This concern with madness as a possible negative result of the initiatory experience is just one aspect of the role Bacchic ("Orphic") initiation played in healing madness sent by evil demons, and it conveys a seriousness to these rites that makes them into something very different from the hobby of some placid burghers. Far from being only the songs that accompanied the tryphé of a Bacchic social event, the hymns point to the emotional complexity and seriousness of Bacchic mystery cults.
\end{abstract}

Résumé : Dans le sillage d'Albrecht Dieterich, cette étude entend montrer comment l'arrangement global des pièces reprises dans le recueil des hymnes orphiques épouse la progression d'un rituel nocturne. On insiste sur la récurrence, dans les hymnes, du motif de la crainte de rencontrer une divinité ou un phasma qui pourrait être malveillant, violent, et frapperait les initiés de folie. Ainsi, les hymnes construisent l'expérience mystérique comme un événement qui est, au moins pour une part, dangereux et effrayant. Ce souci pour la folie comme résultat négatif potentiel de l'expérience initiatique n'est qu'un des aspects du rôle que l'initiation bachique (" orphique») jouait dans la folie curative envoyée par de mauvais démons, et cela confère du sérieux à ces rituels qui étaient quelque chose de bien différent d'un passe-temps pour petits bourgeois placides. Loin d'être seulement les chants qui accompagnaient la truphê d'un moment de sociabilité bachique, les hymnes renvoient à la complexité émotionnelle et au caractère sérieux des cultes à mystères bachiques.

I.

In his Habilitationsschrift of 1891, Albrecht Dieterich (1866-1908) set out to prove the liturgical character of the Orphic Hymns. ${ }^{1}$ He strongly took sides in the yet undecided debate between those who, like himself, regarded the Hymns as ritual texts, and those who thought that they were purely literary creations written, as Lobeck phrased it two generations earlier, "to show how Orpheus

1 On Albrecht Dieterich see R. WÜNSCH, in Albrecht Dieterich. Kleine Schriften, Leipzig and Berlin, 1911, p. XI-XLII; H.D. BETZ, The "Mithras Liturgy." Text, Translation, and Commentary, Tübingen, 2003, p. 14-26 (with earlier bibliography). 
would have taught the best way to pray". ${ }^{2}$ Dieterich's main argument rested on the observation that some of the praying persons are designated as ßouxótor. Using the slowly growing epigraphical record on local religions, he demonstrated that this title reflected actual practice of Dionysiac mystery groups especially in Asia Minor. Over a century later, we have a much larger dossier on these groups: the recent publication by Anne-Françoise Jaccottet contains a long list of Dionysiac "bouviers"3. Dieterich's insight proved to be basically correct, even though his definition needs correction, and his work, together with the research of Otto Kern, established the Orphic Hymns as a liturgical collection ${ }^{4}$. In her commented edition of the hymns, Gabriella Ricciardelli treated the question as settled, and Anne-France Morand a year later was able to look more closely at the underlying Bacchic groups. She did so at some depths; but she also, correctly, took account of the often neglected literary qualities of these hymns, as did Jean Rudhardt whose unfinished study on the Hymns just has been published ${ }^{5}$.

So far, so good. Nobody seems to have serious doubts about the liturgical function of the hymns any more. But there still is Martin West's judgment that all this is not that serious: rather, the eighty-seven Orphic hymns attest to a "cheerful inexpensive dabbling in religion by a literary-minded burgher and his friends" 6 . Given the price of incense in antiquity, I do not know how inexpensive all this would have been. As to its seriousness, it would be all too easy to point out that this argument depends on one's own definition of religion and might contain a mite of Christianocentrism; but I don't want to pursue this line of argument. The underlying question, rather, is that of how to understand Bacchic and Orphic mystery associations: is there a spread from the zealous seriousness of initiates of the ilk of Euripides' Hippolytus (at least in his father's

2 A. Dieterich, De bymnis Orphicis capitula quinque, Marburg, 1891, again in o.c., 70, citing Ch. A. LOBECK, Aglaophamus Sive de Theologiae Mysticae Graecorum Causis Libri Tres, Königsberg, 1829, p. 395: sed potius ... haec mibi sententia est has precationum formulas quicunque composuerit nulli certo aut sacrorum aut hominum generi destinasse sed omnibus, qui deorum aliquem propitiaturi essent, quasi verbis praeire voluisse, non quo crederet quenquam his usurum sed animi causa et ut ostenderet quid Orpheus, si voluisset optimam precandi rationem tradere, praecpturus fuisset.

3 A.-F. ЈАсСОтTET, Choisir Dionysos. Les associations dionysiaques on la face cachée du dionysisme, Zürich, 2003, esp. her index, vol. 2, p. 349.

${ }^{4}$ O. Kern, Zu den orphischen Hymnen, Hermes 24 (1889), p. 498-508; id., "Die Herkunft des orphischen Hymnenbuchs," in Genethliakon für Carl Robert, Berlin, 1910, p. 87-102.

5 G. Ricciardelli (ed.), Inni Orfici, Milano, 2000; A.-F. Morand, Études sur les Hymnes Orphiques, Leiden, 2001; J. RudHARDT, "Recherches sur les Hymnes orphiques," in Ph. Borgeaud and V. Pirenne-Delforge (eds.), Jean Rudhardt: Opera Inedita, Liège, 2008 (Kernos, Suppl. 19), 159-325. Rudhardt planned the study to be exhaustive, p. 176: "Nous en [of the Hymns, FG] considérons d'abord la forme; nous étudierons ensuite les croyances auxquelles ils se réfèrent puis les rituels dont il constituent un élément; nous tenterons enfin de comprendre le type de piété qui les inspire." Of these four parts, only the first two are published and constitute a very thorough analysis of the form and the divine recipients of the Hymns.

${ }^{6}$ M.L. West, The Orphic Poems, Oxford, 2003, p. 29. 
angry reading) to the gaily festivity of a religious Rotary Club meeting? After all, some of the private mystery sanctuaries have an iconography that is characterized by tryphé, as again Jaccottet pointed out ${ }^{7}$. And, if there were such a spread, where do our Hymns fit in, and the association that might be behind them? In order to determine this, I will look at the cheerfulness of what happened in this group, and insert it into the wider world of Dionysiac mystery groups in the imperial time ${ }^{8}$.

II.

I want to start from a remark made by Dieterich which, as far as I can see, has been consistently overlooked. At the beginning of his analysis of the structure of the hymn book, he explains the position of the first two hymns, to Hecate (b. 1) and to (Hecate) Prothyraia (b. 2), not only with the cosmic function of Hecate in $h .1$, as we would expect, but with the function of the Hekataia in Greek architecture: "Nonne et horum mysteriorum sacellum mystas

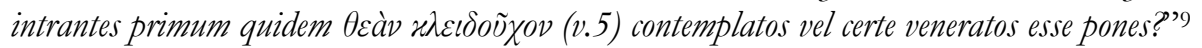
The position of the hymn does not only refer to a cosmogonical ordering of the book (a system Dieterich then adopts for the rest of the book), it reflects ritual reality, the actual experience of the initiates when entering their sanctuary and passing a Hekataion in front of its entrance.

The fact that Dieterich forgets this insight as fast as he had it shows that ritual is not the most obvious organizational principle of the book; the cosmogonical distribution proved more fruitful to him. One might also suspect that Dieterich, despite being a student of Usener, was at this point more interested in theology than in liturgy. But we can still follow the ritual principle as well. The next hymn addresses Nyx. The singer himself calls her a cosmogonical principle ("I address Night, the mother of gods and humans"): this resonates with the Orphic cosmogonies such as the Derveni text that begin their genealogies with $\mathrm{Nyx}^{10}$. But it is very likely that the position of Night refers also, and perhaps mainly, to the time when the ritual took place, as was the case with Eleusis and other mystery rites: the rites begin at sun-set, and they last the entire night ${ }^{11}$. When entering the sanctuary at dusk for the rites, an

${ }^{7}$ JACСOTTET, o.c. (n. 3), vol. 1, p. 161f.; see her index, vol. 2, p. 358 s.v. tryphè.

${ }^{8}$ In citing the Hymns, I use $h$. and the number. My Greek text is a combination of Quandt, Ricciardelli (whom I found the most reliable), and Morand.

${ }^{9}$ DieTerich, o.c. (n. 2), 80.

10 Pap. Derv. col. xiv 6; see also Eudemos, fr. 150 Wehrli = Orph. fr. 20 I Bernabé; W. BurKerT, "Die altorphische Theogonie nach dem Papyrus von Derveni," in: Kleine Schriften. III: Mystica, Orphica, Pythagorica, ed. F. GRAF, Göttingen, 2006, p. 98-99.

${ }^{11}$ See for Dionysus e. g. Eur., Bacchae, 236f. and 486; Livy, XXXIX, 13, 8-10. See the remarks of JACCOTTET, o.c. (n. 3), p. 133 and, in her epigraphical material, esp. nos. 19 (a strange 'midnight

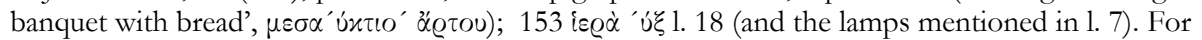
Isis, Apuleius even writes about nox sacrata, Met. XI, 21. 
invocation to Night makes sense. The next hymn, to Ouranos (proving that the overarching ordering principle is the cosmogonical sequence) asks for "a pure life for the newly initiate", ' $80 \varphi \alpha$ ' $\tau \eta \varsigma$ (a word used only here): I regard this not as a coincidence but as a reference to a ritual sequence: we deal with initiation.

Towards the end of the book, we find Night's opposite power, Dawn, h. 78. If the rites begun at dusk, they ended at dawn. The hymn that immediately precedes it addresses Memory, Mnemosyne, and asks her explicitely "to awaken for the initiates the memory of the sacred rite and to send away forgetfulness of it". This is a fitting prayer at the end of the sacred night with its rituals that it is crucial to remember, both because of the immediate bliss they have brought and because of the eschatological consequences: the gold leaves from the graves in Hipponion and Entella again invoke Memory ${ }^{12}$.

If thus one principle of order is the progression of the ritual action, we better understand how the center of the book works, the invocations to Dionysos, his circle and his two mothers, Persephone and Semele. On a first level of understanding, this sequence reflects Orphic mythology, from Zeus seducing Persephone in h. 29 and the result of the seduction, the child Dionysos, in h. 30, to the Titans, "ancestors of our fathers", in h. 37, and from Semele, the second mother of Dionysos, in $h .44$, to the sequence of hymns 45 53 that address various aspects of Dionysos. On a liturgical level, however, one might also think of this long sequence as the center of the entire liturgy. The hymn to Semele is the only hymn that explicitly refers to a ritual act and its etiology: Persephone created for Semele "an honor ( $\left.\tau \mu \eta^{\prime}\right)$ among mortal humans at the time of the trieteris, when they celebrate the birth labor for your Dionysos, the sacred table, and the pure mystery rites":

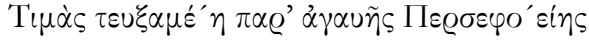

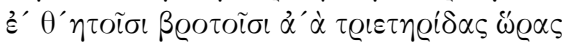

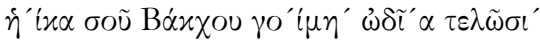

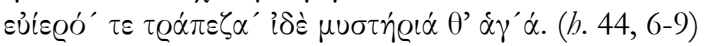

This describes one of the rituals performed during the biannually recurring major festival of Dionysos; it honors Semele's motherhood with what might be public sacrifice (since a gloss in Hesychius gives the festival name $\sum \varepsilon \mu \varepsilon \dot{\lambda} \lambda\langle\eta\rangle \varsigma$ $\left.\tau \varrho \alpha \dot{\alpha} \varepsilon \zeta \alpha^{13}\right)$ and closely connects the mysteries with her: Persephone, the Lady of the Bacchic Mysteries, thus gave a place of honor to the second mother of Dionysos $^{14}$. Semele's "birth labor" is remarkable in the light of the traditional

12 The texts in F. GRAF and S.I. Johnston, Ritual Texts for the Afterlife. The Bacchic Gold Tablets, London, 2007. See Morand, o.c. (n. 5), p. 223f. In the Asklepios rites of Pergamon, however, Memory is invoked at the beginning of the incubation night, Altertümer von Pergamon VIII, 3, no. 156: it is crucial to remember ones dream.

${ }^{13}$ Hesych., s.v.

${ }^{14}$ Morand, o.c. (n. 5), p. 142-144 is rather helpless, and so is Ricciardeldi, o.c. (n. 5), p. 408f. who, however, noted the passage in Hesychius. 
myth where pregnant Semele died well before she could give birth: is it simply a circumlocution for this event, or did this mystery group tell a happier story? One should not forget that several centuries later, a fifth-century CE ivory pyxis in the Museo Civico Archeologico of Bologna depicts what seems the regular birth of Dionysos from his mother; the iconography is unclear enough to make a decision between Semele and Persephone impossible, but other images presuppose Bacchic mysteries as well ${ }^{15}$.

I am aware that this is only a working hypothesis at best, and one that is not easy to prove, except by the argument from the sequence of hymns. But there are other aspects that belong to the collection of the Hymns as a ritual text, and it is to one of them that I turn now.

\section{III.}

All the hymns have a somewhat peculiar structure; Anne-France Morand analyzed it at length and with usefully tabled material. They differ from ordinary ancient prayers in two main ways.

If one looks for the famous and well-researched tripartite structure of ancient prayer - invocatio, argumentum, preces in Ausfeld's term -, the second part is somewhat deficient in the Hymns, compared to other prayer texts; it simply somehow continues the invocation ${ }^{16}$. In regular prayer, this second part has a very clear and distinct function that separates it from the invocation: it establishes the right of the praying person to ask the divinity for help, either because in the past that person has brought lavish offerings, or because the divinity helped in earlier cases and thus the patron-client relationship is already well-established. Even Proclus, whose hymns in many respects are close to the Orphic hymns, regularly introduces such a justification as his second part. Only the Orphic hymns behave differently and shrink this part to an appendix of the invocation. But there is an easy explanation for this anomaly. The praying persons are initiated, and the divinity is well aware of this fact; often enough, the praying persons refer to themselves as $\mu$ ó $\tau \alpha \alpha$. This is enough to establish the close relationship with the divinity that justifies the claim to divine help. This explanation assumes that the hymns are really sung in a mystery ritual performed by initiates only; it does not determine whether they had to be sung all or whether the association could sing some shorter selection.

The second anomaly is that the Hymns do not ask for individual and highly specific divine favors, as does, for example, Chryses in the first book of the Iliad, Sappho in her prayer to Aphrodite or, presumably, countless humans

${ }^{15}$ LIMC, s.v. Dionysos/Bacchus, no. 267. An extensive discussion and good pictures in C. KerÉNYI, Dionysos. Urbild des unzৃerstörbaren Lebens, Stuttgart, 1994, p. 165-168, with fig. 66a-e.

16 See the analysis by RUDHARDT, o.c. (n. 2), p. 194-207 who notes "nous percevons plus facilement la fin du développement que nous ne situons le début”, p. 206. 
every day. Everything these hymns demand from their gods is rather general that the gods be present at the ritual; or that they favor the initiates and help them with their life. More specific things are specific in relation to the divinity only: Eileithyia is asked for good births, Poseidon for help against the dangers of earthquakes and sailing, the Clouds for fertile rain. It is this feature that made the Protestant Lobeck think they were ideal prayers: as he saw it, they do not express individual and egotistic desires, but a concern for general welfare of the liturgical group, or even of the community at large ${ }^{17}$.

As any hymn or prayer, the Orphic Hymns ask the divinity to personally participate in the ritual. One of the recurrent forms which this wish takes is that the divinity might arrive $\varepsilon \dot{\alpha}^{\prime} \tau \eta \tau$ ' adjective is easily understandable ${ }^{18}$. It designates someone who is 'good to meet'; its opposite, $\delta v \sigma \alpha ́$ ' $\eta \tau o \varsigma$ (attested only late) characterizes suffering and disease that is hard to escape ${ }^{19}$. Lucian's Timon talks about his experience when his generosity made him a beggar: suddenly, his former friends disappear around a corner when the spot him from afar, "as if they spotted a sight that was unwelcome to meet and had to be turned away". ${ }^{20}$

To ask a divinity to be 'good to meet' instead of being 'difficult', at a first glance, does not seem spectacular; gods are powerful, and fear is part of epiphany ("jeder Engel ist schrecklich", as Rilke had it), and one wishes to meet their benign side. There is more to it, however, as already Lucian seems to intimate: his language is religious, resonates with the imagery of meeting demons and ghosts. Such an unwelcome demon is a $\sigma \cup^{\prime} \alpha^{\prime} \tau \eta \mu \alpha$, as a Magical Papyrus has it: in this papyrus, the speaker claims that he carries the god's name as a powerful amulet (phylakterion) in his heart, so that no spirit (pneuma), no demon (daimonion), no synanthema nor anything else that belongs to the evils of Hades has power over him ${ }^{21}$. Outside the Hymns, the adjective sú $\alpha^{\prime} \tau \eta \tau o \varsigma$ is mostly used of superhuman beings in their interaction with humans ${ }^{22}$. It is rare and occurs almost only in authors of the Imperial epoch. In inscriptions, again only from the imperial epoch, it occurs in a well-defined religious context: it is

17 To do him justice: Lobeck might well have remembered ancient admonitions to selfless prayer starting with Plato, see A. MOTTE, "La prière du philosophe chez Platon," in H. LIMET and J. RIES (eds.), L'expérience de la prière dans les grandes religions. Actes du Colloque de Lowvain-LaNeuve et Liège 1978, Louvain-la-Neuve, 1980 (Homo Religiosus, 5), p. 173-204.

18 The only scholar who bothered to think about the term was, not surprisingly perhaps, DieTERICH, o.c. (n. 1), p. 79.

${ }^{19}$ LSJ, s.v.

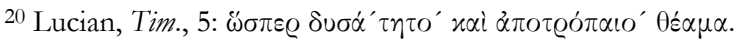

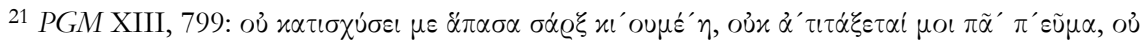

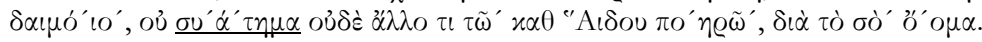

22 The only passage where it is used for a human is Posidipp., Epigr., 25, 1. A few late authors use it several times, especially Oppian and Cyrill of Alexandria who both extend its usage to animals and things. 
always given to the Mother of the Gods, be it in a healing cult in Attica, in an inscription in Egypt or, as Thea Euantetos, in Lydia ${ }^{23}$. The only exception is a dedicatory epigram from Calchedon where it characterizes Poseidon as the protector at sea, in a prayer-like periphrasis. None of these inscriptions gives much context or explains the epithet ${ }^{24}$.

One text deserves more attention. A prayer for lecanomancy, preserved in Hippolytus' Refutatio Omnium Haeresium, addresses Hecate with a long catalog of epithets and identifies her with several female deities and demons: Bombo, Gorgo, Mormo and the Moon Goddess Mene, yet another Anatolian variety of the Great Goddess. At the end, the performer implores her to come euantetos to the sacrifices performed. The echo with the Orphic Hymns is immediate and close, and euantetos has to be taken literally, as Hippolytus makes it clear: "As soon as he has spoken this, you see fire shooting through the air, and they, afraid of this unexpected view, cover their eyes"25. We deal with real and frightening apparitions, at least in the ancient report on the rites: the bodily integrity, the sanity and even the survival of the performers depends on the mood in which the divinity will meet them ${ }^{26}$.

The epithet $\varepsilon^{3} \alpha^{\prime} \tau \eta \tau o \varsigma$, it seems, is not as harmless as one might think. If we then turn back to the Hymns and the use they make of it, the picture is only slightly fuzzier. The epithet appears in five hymns, four times in the final

23 It might be worthwhile to present the small corpus of epigraphical texts:

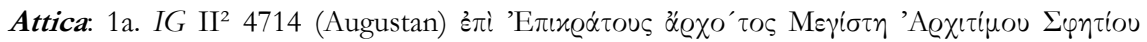

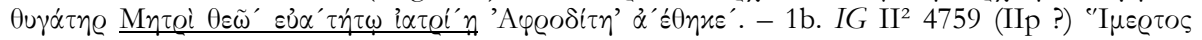

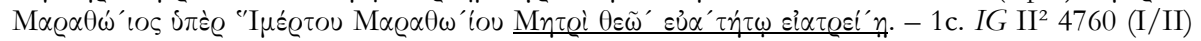

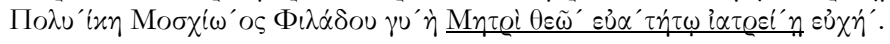

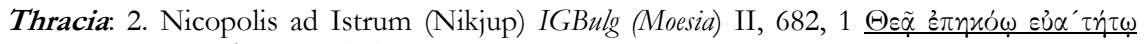

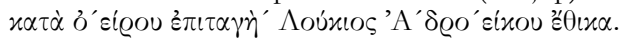

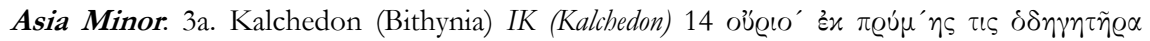

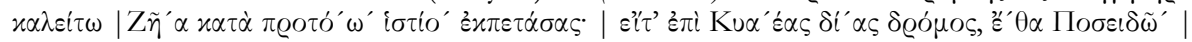

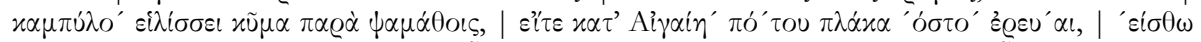

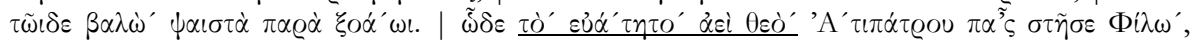

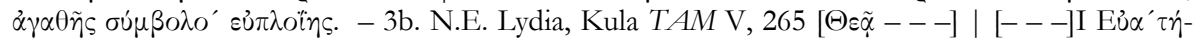

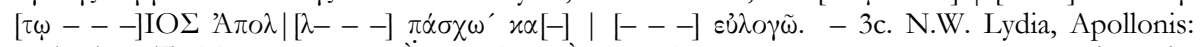

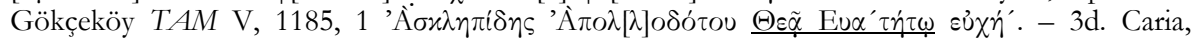

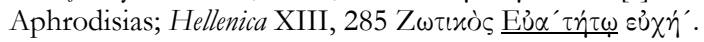

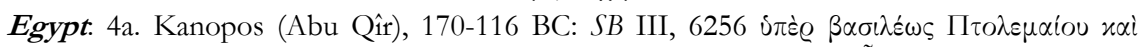

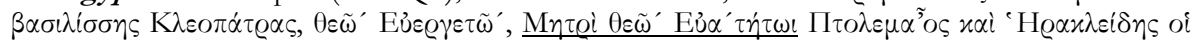

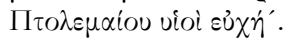

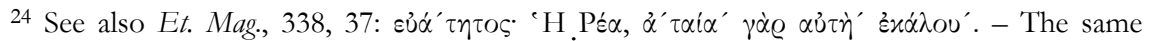
information in Schol. Ap. Rhod. I, 1141, with an allusion to the myth of the Telchines.

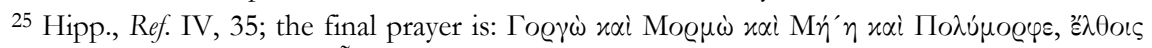

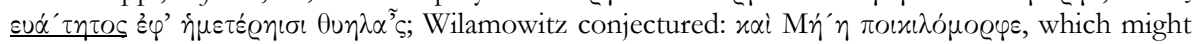
well be right.

${ }^{26}$ In another prayer to Hecate, Apollonius of Rhodes uses the rare cognate $\varepsilon \dot{\jmath} \alpha^{\prime} \tau \eta^{\prime} s, \mathrm{IV}, 148$;

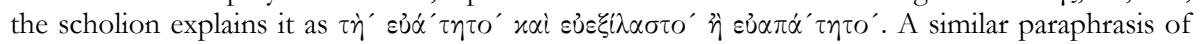

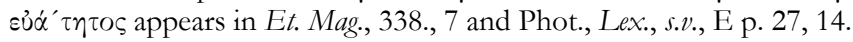


prayer. We could expect it in the case of Meter Antaia, h. 41, 10: she is the form of the Great Mother who meets humans, in a not always friendly way ${ }^{27}$. We might expect it also in the case of Hekate Prothyraia; here, however, it is just one among the many epithets ${ }^{28}$; it does not appear in the final prayer but in the developed invocation. Artemis, who has both this epithet and is asked to arrive as a goddess 'good to meet', fits as well 29 ; she is not only close to Hekate but showed this very quality of being good to meet in an oracle reported by Porphyry, according to which she once prevented Pan, the servant of Dionysos, from killing three woodcutters in the forests around Didyma ${ }^{30}$. Artemis thus can deflect murderous panic (and we retain the information that Pan, the sender of extreme mania, is subordinated to Dionysos). The Kouretes belong to the circle of Cybele; nothing surprising here then ${ }^{31}$. This leaves us with $b .3$, to Night: "Goddess, good to meet, hearken the suppliant's voice, come benevolent and send the Terrors away that shine in the night". Nyx, that is, protects from the terrible and demon-like beings that roam in the dark.

Thus, the picture in the Hymns fits the epigraphical and literary evidence: the epithet characterizes powers that are highly ambivalent and not very welcoming, or (more rarely) that protect from more terrible powers.

What are we to make of this in the context of the Hymns? One answer would be: it all fits the religious world of later antiquity where uncanny powers, ghosts and demons - and the dangers stemming from meeting them - seem to become more visible and, perhaps, more prominent, and one needed protection against all this. The people who were singing these hymns asked for this protection in the same way they asked Poseidon for protection against earthquakes and storms, or Hygieia for help against disease ${ }^{32}$, or as they asked the Titans for protection against angry ancestors: $h .37$ addresses them as "ancestors of our

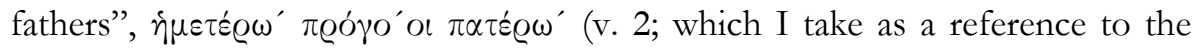
Orphic anthropogony), and asks them "to ward of the difficult anger, if one of the chthonic ancestor should approach our houses”, $\mu \tilde{\eta}^{\prime} \imath^{\prime} \chi \alpha \lambda \varepsilon \pi \dot{\eta}^{\prime} \alpha \pi O \pi \varepsilon \dot{\varepsilon} \mu \varepsilon \varepsilon^{\prime}$,

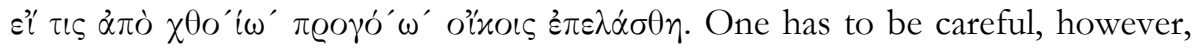
with generalizations like this: already the author of the Derveni papyrus knows of spells with which the magicians ban impeding demons, $\delta \alpha i \mu o^{\prime} \varepsilon \varsigma$ ह $\mu \pi \circ \delta \omega^{\prime}$

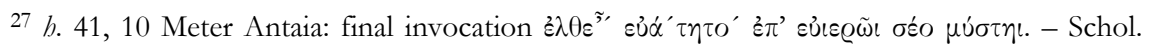
Ap. Rhod. I, 1141 explains her as Meter-Rhea; see above n. 24.

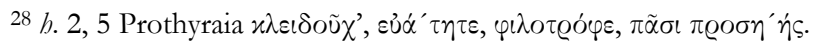

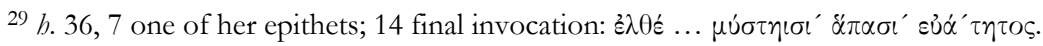

${ }^{30}$ Porph., fr. 307 SMiTH = Eus., Praep. V, 5 f.

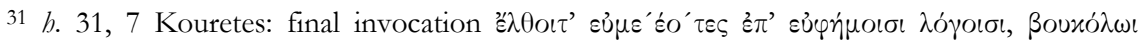

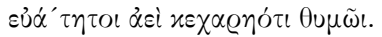

32 Poseidon: h. 17, 10; Hygieia: h. 68, 13. 
whom the Derveni author reads as revenging ghosts ${ }^{33}$; the final prayer of the hymn to the Titans resonates with language in the famous purity law from fourth century Cyrene ${ }^{34}$, and Sarah Iles Johnston has shown the pervasiveness of these believes through the ages: our perception, that is caused again by late antique "loss of nerves", is more a matter of slanted sources and of modern prejudices than of a drastic religious change ${ }^{35}$. But even if we would assume that this was a phenomenon typical only of later antiquity, this would still localize these texts squarely in actually performed religion, and show a seriousness that would go beyond informal playfulness.

There are other indications that the initiates were afraid of visions and the psychic disturbances they create ${ }^{36}$. Hymn 39, to Korybas, asks the addressee to send away his difficult wrath and to "put an end to visions, torments of the terrified soul" 37 . We are again in the world of ecstatic cults, both of Cybele and of Bacchus, but also of the possibility that a divinity might drive a human mad by sending apparitions and ghosts ${ }^{38}$. The same is valid for $h .37$, to the Titans: here, psychic disturbances, mania, from which the Titans protect, result from the wrath of evil ancestors. Other hymns also talk about madness: the

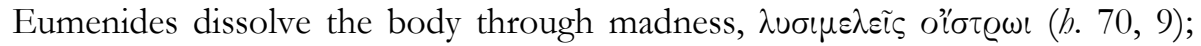
Pan is asked to "send away the panic spur, $\pi \alpha^{\prime}$ เxò' ỡ $\sigma \tau \varrho o^{\prime}$, to the ends of the world" (h. 11, 23); and Melinoe, to whom I will return, "drives humans mad

33 Pap. Derv, col. vi 2-7. See G. Betegh, The Derveni Papyrus. Cosmology, Theology, and Interpretation, Cambridge, 2004, p. 14 and Th. Kouremenos, G.M. Parássoglou, K. Tsantsanoglou (eds.), The Derveni Papyrus Edited with Introduction and Commentary, Florence, 2006, p. 168.

34 b. 37, 7f. - See F. SOKOLOWSKI, Lois sacrées des cités grecques. Supplément, Paris, 1962, no. 115 B 29, with R. PArker, Miasma. Pollution and Purification in Early Greek Religion, Oxford, 1983, p. 347; somewhat less close the law from Selinus, M.H. JAmeSON, D.R. JordAN, R.D. Kotanksy, A Lex Sacra from Selinous, Durham, NC., 1993.

35 S.I. Johnston, Restless Dead. Encounters Between the Living and the Dead in Ancient Greece, Berkeley/ Los Angeles, 1999, passim. - It was E.R. Dodds who most influentially expressed the stereotype; I suspect that it had its tremendous impact especially because it resonated so well with contemporary culture; after all, "the phrase [Age of Anxiety] was coined by my friend W.H. Auden who applied it to our own time", Pagan and Christian in an Age of Anxiety, Cambridge, 1968, p. 3.

${ }^{36} \mathrm{I}$ do not enter into a discussion of $h .32,6$ where Athena is said to send madness to humans: it is in her role as divnity of war that she acts this way.

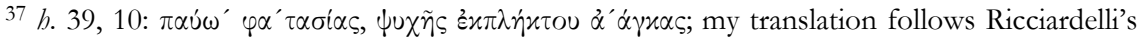
"tormenti dell'anima intimorita." On Korybantes and psychic disturbances, H. JEANMAIRE, "Le traitement de la mania dans les "mystères" de Dionysos et des Corybantes," Journal de Psychologie (1949), p. 64-82 and Dionysos. Histoire du culte de Bacchus, Paris, 1951, p. 119-131 (on modern parallels) and 131-138 (on the Corybantic rites); E.R. DoDDS, The Greeks and the Irrational, Berkeley, 1951, p. 77-79. Jeanmaire's paper has been eclipsed by the fame of Dodds's book, at least in the Anglophone world, quite unjustly so.

38 The Corybants are not only acolytes of Cybele, they also dance around the child Dionysos on a few images that range from Hellenistic times to late antiquity and that seem to have a connection with Orphic mythology again, see W. BURKERT, "Bacchic Teletai in the Hellenistic Age," in T. CARPenter and C.A. FARAOne (eds.), Masks of Dionysus, Ithaca, N.Y., 1993, p. 271, reprinted in Kleine Schriften III (n. 10), p. 130-131. 
with airy ghosts", $\theta^{\prime} \eta \tau o \dot{s} \varsigma \mu i^{\prime} \varepsilon \iota \varphi \alpha^{\prime} \tau \dot{\alpha} \sigma \mu \alpha \sigma \iota^{\prime} \eta \dot{\eta} \varepsilon Q i o \iota \sigma \iota(h .71,6)$, and is asked to

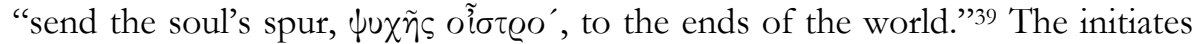
seem to live in a world that is filled with threats of madness. After all, their first hymn invoked Hecate not just as the key-holder of the cosmos but as a divinity

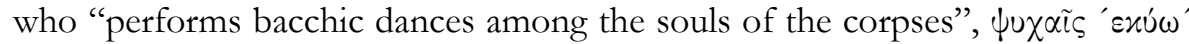
$\mu \varepsilon \dot{\tau} \alpha \beta \alpha x \chi \varepsilon \dot{O} 0 v \sigma \alpha$, and who is much more difficult to meet than any other

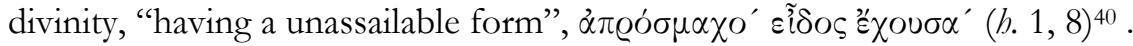

\section{IV.}

But there might be more. It is specially the mystery rituals in which the initiates meet the divinities almost face to face - or at least this is the way the Greek and Roman religious imagination shaped the experience to which mystery rituals gave rise. When the Eleusinian hierophant called Kore, he sounded the gong, and (no doubt) Kore appeared ${ }^{41}$. The purified Eleusinian initiate is able to touch the snake on Demeter's lap, in an image on the so-called Urna Lovatelli, an early Imperial urn from a Roman columbarium 42 . "I met the gods below and the gods above and worshiped them face to face:" thus Apuleius' Lucius describes the central experience of the Isis rites ${ }^{43}$. Dionysos and Ariadne's blissful presence dominates the ritual fresco of the Villa dei Misteri in Pompeii. Not all powers, however, were conferring bliss. Athenians knew of the empusa, an attacking demon who frightened the Eleusinian initiates, presumably only if they had not been properly purified before the rites, as Jamblichus seems to intimate ${ }^{44}$. Aeschines' mother famously had the same nickname Empusa, in one explanation because she jumped unexpectedly at her clients when she was performing her initiation rites ${ }^{45}$ : even though this is only one of two rivaling ancient explanations, it would not have been credible if the fear of frightening demons did not play a role in ancient mystery cults ${ }^{46}$. Thus, initiates could fear the frightful appearance of some divinities, especially divinities that were felt to be more threatening than others outside the mystery rites as well. And it was especially the powers that dwelled outside the safe

${ }^{39}$ Eumenides, h. 70, 9; Pan h. 11, 23; Melinoe h. 71, 6, 11. See Morand, o.c. (n. 5), p. 185, on oĩot@os: "Ce terme évoque la folie et la peur".

40 On cosmic Hecate, see S.I. Johnston, Hekate Soteira. A Study of Hekate's Roles in the Chaldaean Oracles and Related Literature, Atlanta, 1990, p. 40-42.

41 Apollodoros, FGrHist 244 F 110.

42 ThesCRA II, p. 96 no. 34, with the earlier bibliography; see esp. W. BurKerT, Ancient Mystery Cults, Cambridge, Mass., 1987, p. 94f., with fig. 4.

43 Apul., Met. XI, 23.

44 Main passages Ar., Ran., 293 (with Scholia) and Iamb., Myst. III, 31, 178, 8-16 Des PlaCeS; see also Clem., Strom. IV, 1, 3.

45 Dem., Or. 18, 130; the explanation Idomeneus of Lampsacus, FGrHist 338 F 2.

46 See the discussion in Chr. G. Brown, "Empousa, Dionysus and the Mysteries. Aristophanes, Frogs 285ff.," CQ 41 (1991), p. 41-51 and JOHNSTON, o.c. (n. 35), p. 131-138. 
space of the city who were perceived in this way, such as the Mountain Mother and her followers, the Kouretes and Corybants, or Artemis and Hecate.

In this context, the hymn to Night, $h .3$, gains more weight. We saw that the position of this hymn immediately after the one to (Hekate) Prothyraia might resonate not only with Orphic cosmogony as an ordering device of the hymns book, but also with ritual reality. After an exposition of Night's mythical and real functions, the hymn addresses the specific wish to her:

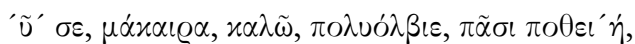

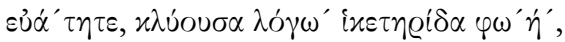

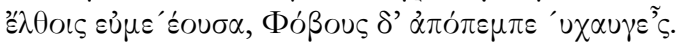

Now, blessed one, I call upon you, blissful and all-desired one, benign to meet, hearken to my pleading voice and come full of good will, send away the terrors that shine in the night ${ }^{47}$.

Above, we understood it as one of those prayers that humans in preindustrial society were addressing to a protective power because they feared that demons and specters were loose in the dark of the night; Christian hymns regularly attest to these terrible fears ${ }^{48}$. Maybe that is all. But if, in the sequence of rituals that shaped the initiates' experience, this hymn really marked the beginning of the nocturnal rites, the prayer would acquire additional poignancy: the goddess Night protects the praying initiate, whose voice the text preserves, from the specters that appeared during the mysteries, and that otherwise might be too terrifying to tolerate.

\section{V.}

In the context of Dionysiac mysteries, such fears seem even more appropriate than in almost any other cultic context, perhaps with the exception of inspired divination. After all, the central experience of the Dionysiac initiates was $\mu \alpha^{\prime} i \alpha$, 'frenzy'; and although Dodds coined the description of the 'blessings of madness' in the very context of Dionysiac cult, these blessings were very mixed indeed.

One of the mythical aitia of the cult of Dionysos makes this explicit. Apollodorus' Library contains the story how Hera drove young Dionysos mad; "he roamed about Egypt and Syria [...] and arrived at Cybela in Phrygia: there, he was purified by Rhea, learned from her the rites of initiation $(\tau \varepsilon \lambda \varepsilon \tau \alpha \imath)$ and

47 b. 3, 12-14. Quandt omits $\lambda$ ó$^{\prime} \omega^{\prime}$ in 13, following the majority of the mss., and so does Morand; Ricciardelli retains it, follwoing $\varphi$, one of her two hyparchetypes. It might well be a conjecture in a metrically deficient verse, as R. Keydell assumed, in his review of G. Quandt (ed.), Orphei Hymni, in GGA 204 (1942), p. 78.

48 Beginning with Ambr., Hymn., 10, 5: fuga catervas daemonum, or Prud., Cathem. I, 37-40: ferunt vagantes daemonas laetos tenebris noctium, gallo canente exterritos sparsim timere et cedere. 
received the long robe; then he pressed through Thrace towards India"49. The story goes back to the Europia, an epic poem by the rather shadowy Eumelus whom ancient scholars dated as early as Homer: "Dionysus [...] was purified in Kybela in Phrygia by Rhea and received from her the entire ritual outfit" 50 ; in this version, part of the outfit was the golden crater which he then handed over to Thetis. Madness, $\mu \alpha^{\prime} i \alpha$, is something from which Dionysos has to be healed, and his mysteries are embedded into this process. The story is no secret mystery lore: it is depicted on an altar from the Coan agora, dated to the midsecond century $\mathrm{BCE}^{51}$.

The two texts are silent about the exact relationship between mysteries and madness. One reading is that the Dionysiac $\tau \varepsilon \lambda \varepsilon \tau \alpha i$ heal madness; that is what the Orpheotelests in Plato promise and with what, according to Orpheus' hexameters cited by Olympiodorus, Dionysos Lyseus is concerned ${ }^{52}$. That is also what the hymn to the strange goddess Melinoe, $b .71$, asks her to do: the initiates pray to her "to send the soul's spur to the limits of the earth, showing

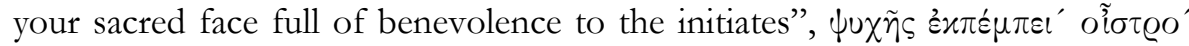

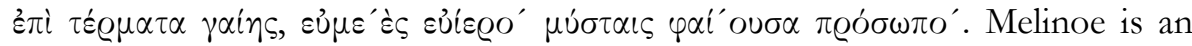
angry underworld divinity, and she is angry because her step-father, Hades, raped her; in the same way, her grand-mother Demeter had turned into Erinys after Poseidon raped her ${ }^{53}$. "She drives humans mad with airy ghosts", as the hymn explicitly asserts. But the goddess is, at the same time, intimately connected with the mysteries of Dionysos: in the myth narrated in her hymn, she is the daughter of Zeus and Persephone and thus the sibling sister of Dionysos himself, according to Orpheus' version of Dionysos' genealogy. Given the rarity of myths narrated in the Orphic hymns, this myth must belong to the lore of these Orphic mysteries, and the otherwise unattested divinity belongs firmly into this specific world of a local Dionysiac mystery cult ${ }^{54}$.

But Dionysiac ritual, $\beta \alpha x \chi \varepsilon v^{\prime} \varepsilon i^{\prime}$, is in itself $\mu \alpha i^{\prime} \varepsilon \sigma \theta \alpha$. As one of the Hymns puts it, Dionysos dances with the nymphs, driven by madness, é $\lambda \alpha v^{\prime}$ ó $\mu \varepsilon^{\prime} \circ \varsigma$ $\mu \alpha^{\prime}$ in $\iota \iota^{55}$ : the relationship between the god and madness is more complex than Dodds assumed. The underlying idea seems to be that Dionysos' $\mu \alpha^{\prime} i \alpha$ is safe, and that it can preserve the initiate from madness which is understood as a disease. If I may use a modern analogy, Dionysiac madness is a sort of

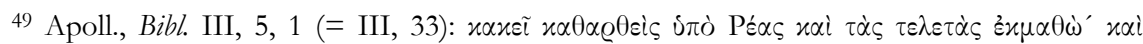

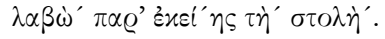

50 Eumelos, fr. 11 Bernabé (= Schol. A Iliad. VI, 131); Schol. Lycophr., 273: $\lambda \alpha \beta \dot{\omega}^{\prime} \pi \tilde{\alpha} \sigma \alpha^{\prime}$ $\pi \alpha \varrho \dot{\alpha} \tau \tilde{\eta} \varsigma \theta \varepsilon \tilde{\alpha} \varsigma \tau \dot{\eta}^{\prime} \delta \iota \alpha \sigma \varkappa \varepsilon u \eta^{\prime}$.

51 Detailed account BURKERT, l.c. (n. 38), 271-274 = Kleine Schriften III (n. 10), p. 131-134.

52 OF 232 KERN = fr. 350 BERNABÉ.

53 JOHNSTON, o.c. (n. 35), p. 258-264.

54 On Melinoe, see Morand, o.c. (n. 5), p. 181-188.

55 h. 46, 5; the textual problem of this verse is irrelevant for my argument. 
vaccination, performed with a real strain of live bacteria, but weaker and controlled; but as any vaccination might contain the danger of a real outbreak of the illness, thus the mysteries of Dionysos contain the danger of real madness - witness the many stories told about the men and women really driven to murderous madness by the god.

In this context, both the prayer to Melinoe as well as the several prayers that ask for a benign encounter might gain an additional dimension: the initiates, confronted during their rituals with all these terrible divinities, ask for the absence of the wrong and horrifying side of madness. Although only myths talk about such a fate, such as the stories of Pentheus, Agaue or of the daughters of Proiteus, these stories could always nurture the fear that such a thing might happen during the rites - or, to turn it another way, by evoking these fears, the Orphic Hymns construct their experience as a terrifying one, at least in part. This is not different from the Eleusinian experience: in Plutarch's well-known description, it progresses from "every terrible thing, panic, trembling, sweat and

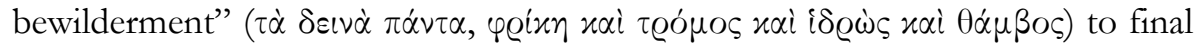
bliss - or, to cite again Plutarch: an experience where "a marvelous light meets you, pure places and meadows receive you, with voices (i.e. singing), dancing

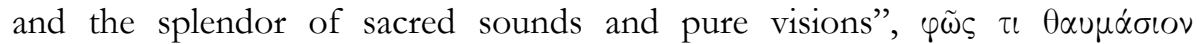

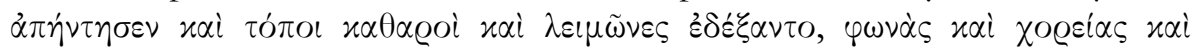

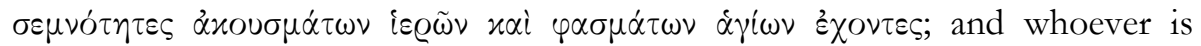

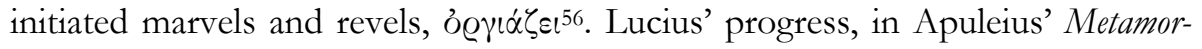
phoses, from meeting the powers of the underworld to worshipping the gods in the sky follows the same emotional trajectory, and there can be no reasonable doubt that the same held true for the Bacchic mysteries.

\section{VI.}

One way to protect oneself is prayer, as we hear it in the hymns. Another way is purity; we remember that Jamblichus talks about the evil spirits who hinder those initiates who have not been adequately purified ${ }^{57}$. Purity is important in the Hymns, but it is rarely expressed beyond the simple use of adjectives such as $\alpha \gamma_{10}$ and $x \alpha \theta \alpha \varrho o ́ s$. But there are some instances that give more. In the hymn to Eros, the initiates pray that the god would meet them with pure thoughts and keep them away from all bad and outlandish drives,

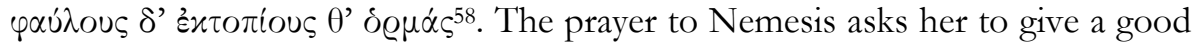
mind $(\delta \iota \dot{\alpha} v o \iota \alpha)$, put an end to all hateful human thoughts that are unholy, utterly

\footnotetext{
56 Plut., fr. 178 SANDBACH.

${ }^{57}$ Iamb., Myst. III, 31 (cp. above n. 44).

58 h. 58, 10 - more than just "gli slanci sconvenienti", as RiCCIARDELli, o.c. (n. 5), p. 459 comments, this points to more severe restrictions, as MORAND, o.c. (n. 5), p. 218 saw - not necessarily to "l'abstinence sexuelle," but to sexual ethics such as the mystery law from Philadelphia expresses (see n. 60).
} 


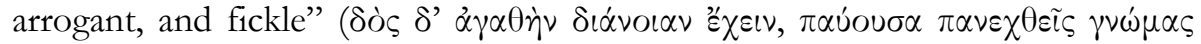

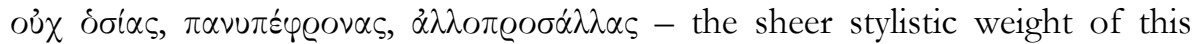
ending indicates its importance $\left.{ }^{59}\right)$. These prayers locate the Bacchic association not too far away from the cultic group in Philadelphia whose sacred law extensively talks about purity, not the least sexual purity ${ }^{60}$. But a passage from another contemporary sacred law of Western Asia Minor is even more relevant; it comes from the hexametrical rules of the association of Dionyos Bromios in Smyrna ${ }^{61}$. Here too, purity is the overarching theme, from rules how to behave in cases of miscarriage and death to the sacrificial taboos on beans and heart. At one point only, the text alludes to the consequences of impurity: purity is important, "lest a cause for wrath arises", $\mu \dot{\eta} \delta \dot{\eta} \mu \dot{\eta} \nu \mu \mu \alpha \gamma^{\prime} \varepsilon \eta \eta \alpha \iota$. This is clear enough for the audience, they know the consequences of divine wrath: one is madness, according to the Phaedrus ${ }^{62}$.

\section{VII.}

It is time for a summary. In this paper, I have not tried to show that the Orphic hymns reflect a liturgical reality; after all, Dieterich had already done so. I have however tried to show how the overall arrangement of the hymns in the book follows the progression of the nocturnal ritual; this then has to be added to the other criteria of arrangement that have been analyzed by Dieterich and, recently, by Anne-France Morand. And I have especially tried to show how often the hymns talk about the fear of meeting a divinity or a phasma who would be in an unkind and violent state: such an encounter might drive the initiates into madness. Thus, the initiates construct their experience as an event that is, at least in part, dangerous and frightening. This concern with madness as a possible and negative result of the initiatory experience is just one aspect of the role Bacchic, Orphic initiation played in healing madness sent by evil demons. All this, then, conveys a seriousness to these rites that makes them into something very different from the hobby of some placid burghers. Far from being only the songs that accompanied the tryphé of a bacchic social event, the hymns point to the emotional complexity and seriousness of Bacchic mystery cults.

The Ohio State University

Fritz GRAF

Department of Greek and Latin

Columbus, OH 43210-131

E-mail:.graf.65@osu.edu

\footnotetext{
59 h. 61, 11-12.

${ }^{60}$ F. SoKolowski, Lois sacrées de l'Asie mineure, Paris, 1955, no. 20, 1. 25-32.

${ }^{61}$ SOKOLOWSKI, o.c. (n. 50), no. 84 = JACCOTTET, o.c. (n. 3), no. 126.

${ }^{62}$ Plato, Phaedrus, 244d-e.
} 